Annals of Tropical Research, 33(1): 101- 119 (2011)

\title{
Why Are There So Few Carbon Offset Projects in Pacific Island Countries?
}

\author{
Paul Dargusch $^{1}$, Shaun McMahon ${ }^{1}$, Sebastian Thomas ${ }^{2}$ and Ray \\ Collins $^{1}$
${ }^{1}$ School of Agricultural and Food Sciences, The University of Queensland, Brisbane 4072 Australia
${ }^{2}$ School of Business, The University of Queensland, Brisbane 4072 \\ Australia
}

\begin{abstract}
This article examines reasons for the lack of Clean Development Mechanism (CDM) projects registered in Pacific Island Countries (only two of the 1699 projects registered as of 1 July 2009 were located in such countries) and assesses the potential for new project development in the region. Two groupings of CDM projects are analyzed. First, features of the eight CDM projects located in Small Island Developing States and Territories that were registered as of 1 July 2009 are examined to identify what factors have characterized successfully registered CDM projects. (No new projects have been registered in SIDS since this date, although there are more projects currently being validated.) Second, the 122 agricultural-based CDM projects registered as of 1 July 2009 are analyzed to consider how agricultural and bioenergy projects - which seem the most suitable form of CDM projects for the Pacific Islands region - can be best developed in the region. Analysis reveals that agricultural CDM projects that generate electricity have strong potential for development in the Pacific Islands. Policy options to support electricity generation projects are discussed, including the establishment of a regional CDM body, the possibility of Pacific Island countries engaging in unilateral CDM projects, and the role that 'regional economic leaders' such as Australia could play to assist project implementation.
\end{abstract}

Keywords: small-scale projects, clean development mechanism, CDM, SIDS

\section{INTRODUCTION}

The Clean Development Mechanism (CDM) was established under the Kyoto Protocol to assist in achieving sustainable development and emissions reductions in developing countries, while providing a flexible and cost-effective means for developed countries to comply with their greenhouse gas emissions targets (UNFCCC, 2009). The CDM achieves this by allowing entities from Annex I (developed) countries to develop emission-reducing projects in non-Annex I (developing) countries, generating tradable credits corresponding to the volume of emission 
reductions. These tradable credits, known as Certified Emission Reductions (CERs), are each equivalent to one ton of abated $\mathrm{CO}_{2}$ equivalent and can be used to meet emissions compliance targets or sold to entities that require them for compliance under domestic legislation in developed (Annex 1) countries.

The global market for CERs has grown rapidly. As of July 2009 there were over 4500 projects in the CDM pipeline, with the theoretical potential of delivering about 2.9 billion CERs by 2012 (Capoor and Ambrosi, 2009). In 2008 the secondary market for CERs (meaning speculative trades of CERs after their purchase from offset projects) was the second largest segment of the carbon market, with a traded value exceeding US\$26 billion. However, it is unclear whether the rapid growth of the CDM is representative of market success, because evidence continues to emerge of tradeoffs between the CDM's two fundamental goals (Olsen, 2009). Previously, the geographic and project distribution of the CDM have been highly skewed (Ellis and Kamel, 2007), with CDM projects and CERs concentrated within a few countries. China, India, Brazil and Mexico account for approximately $75 \%$ of the proposed projects, and $80 \%$ of the total expected credits (UNFCCC, 2009b). Particular project types feature prominently in the CDM; projects involving the destruction of industrial gases (hydrofluorocarbons or HFC-23 and nitrous oxide or $\mathrm{N}_{2} \mathrm{O}$ ) account for $40 \%$ of the expected annual credits in the CDM pipeline. These project types are effectively the 'low hanging fruit', characterized by short lead times and large volumes of credits in exchange for low capital investment and transaction costs (Ellis and Kamel, 2007). Olsen (2007) argued that the distribution of the CDM portfolio reveals that the CDM has been successful in achieving low-cost emission reductions, but is yet to achieve commendable sustainable development benefits (Boyd et al., 2009).

There are 20 Pacific Island Countries (PICs). The United Nations Department of Economic and Social Affairs (UNDESA) recognizes 51 Small Island Developing States and territories (SIDS) globally in three regions: the Caribbean, the Pacific and the AIMS areas (Africa, Indian Ocean, Mediterranean and South China Sea) (UNDESA, 2009). These countries face similar challenges resulting from their small populations, limited resources, geographic isolation, susceptibility to extreme weather events and dependence on international trade and aid. The near exclusion of SIDS from the CDM portfolio supports Olsen's (2007) argument. Only eight CDM projects have been registered in SIDS and of these only two are in PICs (UNFCCC, 2009b). This is noteworthy considering that SIDS are particularly exposed to the effects of climate change, with limited adaptive capacity (Grasso, 2006). Climatic change is predicted to directly affect a multitude of social and environmental conditions, from biological systems and water resources to agriculture, fisheries, infrastructure and human health (Byrne et al., 2005).

PICs are characterized as archipelagic landmasses with high population densities in coastal areas, a lack of arable land and fresh water resources, and remoteness from neighbouring states and markets (Holden et al., 2004). By the end of 2008, the population of the PICs was estimated to have reached $9.5 \mathrm{M}$, with the majority concentrated in the region's largest four countries: Papua New Guinea (PNG), Solomon Islands, Fiji and Vanuatu. The region is experiencing high demographic stress, with population growth rates of approximately $2.2 \%$ annually, rapid urbanization and population distribution concentrated in lower and higher age ranges 
(Haberkorn, 2004). The continued growth of coastal settlements increases risk of exposure to storm surges, flooding and coastal erosion (Burns, 2000). The economies of PICs are relatively undiversified and dominated by agriculture, fisheries and tourism industries, all of which are highly susceptible to climatic change. Increasing temperatures and sea-level rise resulting in ocean acidification and coral bleaching will threaten coastal fisheries, which account for over $70 \%$ of some countries' total national exports, and are vital for food security (FAO, 2009). Further, reduced water supply, increasing soil salinity, erosion and extreme weather events are all likely to affect negatively agricultural production (Department of Climate Change, 2009).

Despite collectively producing less than $1 \%$ of global greenhouse emissions, PICs have demonstrated an ardent commitment to reducing their contribution. The Pacific Islands Framework for Action on Climate Change (2006-2015) outlines the region's priorities as: implementing adaptation measures; governance and decision-making; improving understanding of climate change; education, training and awareness; contributing to global greenhouse gas reduction; and partnerships and cooperation (SREP, 2005). Specifically, the framework identifies CDM initiatives as an appropriate means to support these priorities. Nonetheless, the ability of Pacific Island governments to address climate change is constrained by their limited resources and need to focus on more immediate development challenges (Department of Climate Change, 2009). PICs are second only to sub-Saharan Africa in their lack of progress towards achieving the Millennium Development Goals (Van der Velde et al., 2007). This is exemplified by the inadequacy and inefficiency of energy supply and related services in the region (Roper, 2005). The energy and transport sectors in PICs are served almost entirely by fossil fuels, making per capita consumption of fossil fuels relatively high (McGregor, 2009). Dependence upon imported fuels exerts substantial cost pressures on the economies of PICs. Economic activity can be depressed by price shocks in international markets, governments are burdened by ineffective subsidies, and high transport costs are passed on to consumers (Byrne et al., 2005). Furthermore, diesel-based electricity generation (often rationed in favour of commercial users over households) contributes substantially to air pollution (Byrne et al., 2005; Roper, 2005; McGregor, 2009). The World Bank has reported that household access to electricity can be as low as $7 \%$ in some rural areas, with households spending $25 \%$ or more of their income on fuel for power generation as well as transport (World Bank, 2007). Accordingly, there is a strong case for the development of renewable energy sources, as well as the requisite technical and institutional capacity, in the Pacific Islands.

This paper addresses the question: 'Why are there so few CDM projects in PICs and how can more be developed?' The paper then presents analysis of two groupings of CDM projects. The characteristics of eight CDM projects located in SIDS around the world that were registered as of 1 July 2009 are analyzed to identify what features have characterized successfully registered CDM projects in similar socio-economic and geographic circumstances to the Pacific Islands region. Interestingly, no new CDM projects have been registered in SIDS since this date. Then the 122 agriculturalbased CDM projects registered as of 1 July 2009 are examined to shed light on how agricultural and bioenergy projects - which seem the most suitable form of CDM projects for the Pacific Islands region - can be best developed in PICs. Implications 
are then drawn for improved climate change mitigation and energy policy in the Pacific region.

\section{LITERATURE REVIEW}

Many SIDS exhibit poor institutional and governance capacity across both private and public sectors (Van der Velde et al., 2007). The absence of a holistic institutional framework encompassing energy, and legal and regulatory policies, has inhibited the proliferation of CDM projects. McGregor (2009) noted that in Fiji, private sector power producers seeking to feed electricity to the grid have faced resistance from the Fiji Electricity Authority (FEA). Similarly, Roper (2005) identified a lack of commitment by governments and key administrators in PICs, compounded by poor capacity to plan, to develop and maintain facilities, as a major obstacle to renewable energy projects. An effective governance framework within a country is imperative, because administrative practices are considered by investors as a proxy for the commitment and capability of the government (Ellis and Kamel, 2007). An investor's decision to engage in a CDM project in a particular host country will be influenced by the perceived efficiency of government regulatory frameworks and processes.

Targeted CDM-related institutional frameworks have been shown to influence the number and type of CDM projects within a country, and the efficiency at which the project cycle can be completed (Ellis and Kamel, 2007). An effective institutional framework requires adequate knowledge of CDM regulations and procedures, and the ability to facilitate the completion of CDM transactions in a timely and transparent manner. Aside from ratifying the Kyoto Protocol, the principal requirement for a host country to participate in the CDM is the establishment of a Designated National Authority (DNA). The primary role of the DNA is to approve proposed CDM projects by confirming that participation in the project is voluntary, and that the project activity contributes to sustainable development (UNDP, 2003). Presently, only two DNAs have been established in PICs (one in Fiji and one in Papua New Guinea). Progress to develop the necessary institutional frameworks has been painstakingly slow (Kwa, 2008).

Related to the absence of adequate institutional frameworks in PICs is the limited diffusion of information concerning CDM opportunities (McGregor 2009). A lack of awareness of the CDM exists among policy-makers and private investors in the region (Gender CC 2008; McGregor 2009). A lack of knowledge about carbon markets among policy-makers can result in the introduction of regulations and policies that stifle growth in CDM activities (Ellis and Kamel, 2007). This deficit of carbon market knowledge has impeded the ability of PICs to lobby and engage effectively in CDM capacity-building negotiations with important stakeholders (McGregor, 2009). Awareness of carbon market opportunities among potential project-sector parties (such as energy and waste management practitioners) is required to engage proponents to assist with project development and initial resource provision. Roper (2005) observed that electricity utilities within PICs are dependent on established diesel technology, and lack experience and resource assessments in renewable energy. Such limited understanding impairs informed decision-making, and results in a reluctance to engage in CDM projects (McGregor, 2009). A comprehensive knowledge base (of 
international policy instruments, clean technologies, and finance mechanisms) within the local financial sectors of PICs is also necessary in order to reduce the perceived risk of funding CDM projects that employ unfamiliar technologies (Van den Berg and Langenberg, 2006).

Finance-related issues are another challenge inhibiting CDM project development in PICs. Because transaction costs are fixed, small projects incur relatively high average costs per CER, making them less attractive to investors (Van den Berg and Langenberg, 2006). This was the fundamental premise underlying the development of small-scale methodologies under the CDM, which apply simplified procedures and permit project bundling to reduce risk of project failure and transaction costs (UNDP 2003). However, small-scale projects are still likely to be considered unfavourably by financial intermediaries and investors, because economies of scale also exist in the performance of due diligence and information processing (Van den Berg and Langenberg, 2006). As well, the preferences of CER buyers and CDM investors towards specific geographic areas and project types may pose a barrier for PICs. The growth of carbon funds that stipulate minimum project sizes (and therefore favour larger projects) or those that reduce emissions of gases with a higher global warming potential (e.g. HFC-23) explicitly discriminate against SIDS (McGregor, 2009).

PICs also exhibit a number of geographic and demographic traits that constrain their capacity to engage in the CDM. While the potential benefits of renewable energy projects that displace diesel electricity generation in island countries are well recognized, a number of factors, including access to capital, remoteness and geographic dispersion, and inadequate indigenous skills and management capabilities, constrain their viability (Van der Velde et al., 2007; McGregor, 2009). As the premise of the CDM is to generate low-cost emission reductions, it has favoured nations that are large emitters and possess infrastructure and resources that are appropriate for particular project types. Investment costs for 'add-on' CDM projects which improve the environmental performance of an existing facility tend to be lower than 'greenfield' projects such as wind farms (Ellis and Kamel, 2007). SIDS offer few large-scale manufacturing and industrial contexts to which CDM projects can be attached (Van der Velde et al., 2007). In contrast, they present opportunities for specific small-scale projects which require special technical investment.

PICs are also isolated from major markets and some are a collection of small islands dispersed over a large area (Holden et al., 2004). This 'tyranny of distance' has economic and administrative implications relevant to their participation in the CDM. Isolation from major markets restricts access to CER buyers and technical practitioners, including Designated Operational Entities (DOEs) that verify project emission reductions. Their geographic distribution increases administrative costs (Gender, 2008). Further, susceptibility to severe climatic events reduces their attractiveness, and extensive damage caused by such occurrences (made more frequent by climate change) increases the level of perceived country risk, raising capital costs and limiting access to foreign investment (Holden et al., 2004). While some small states receive substantial inflows of foreign direct investment (FDI), most Pacific economies receive less per capita than the average for SIDS. Thus, ironically, the ability for PICs to obtain capital to finance CDM projects is hampered by their vulnerability to the events they are trying to prevent. PICs also suffer from human 
capital drain through emigration, in that the most capable entrepreneurs pursue greater opportunities abroad (Holden et al., 2004). This phenomenon results in private sectors in these countries that lack the skills to generate innovative projects and proposals, or to manage aid projects financed by donors. Potential CDM developers typically lack the necessary expertise required to source funding and prepare the relevant documentation, as well as the technical knowledge to operate CDM projects (Ellis and Kamel, 2007). The additional expenses incurred to attract the consultants, technical practitioners and local staff increase the investment costs of CDM projects in the Pacific region.

\section{LESSONS FROM CDM PROJECTS IN OTHER SMALL ISLAND NATIONS}

A summary of the 8 projects registered by July 2009 is presented in Tables 1 and 2 . Apart from the Singapore project, each of the Project Design Documents (PDDs) states that a key objective is to 'reduce reliance on foreign fuel' or 'diversify energy generation' in the country. As a consequence, a number of project documents noted that by improving energy stability they hoped to encourage investment and stimulate economic growth. Of the projects, six are large-scale, generating on average 160,915 $\mathrm{tCO}_{2} \mathrm{e}$ CERs per annum, and the two small-scale projects generate an average of approximately 20,000 $\mathrm{tCO}_{2} \mathrm{e}$ CERs annually. The dominance of large-scale projects, despite the lack of large-scale renewable energy potential, suggests that developers are sensitive to economies of scale. Similar barriers are reported to the development of the projects across the countries, and include lack of knowledge and expertise in proposed technologies which increases investment risk and investment costs; absence of supportive policies and regulatory frameworks; high levels of risk based on national characteristics; shortages of skilled labour; vulnerability to severe weather events; low quality infrastructure; and high initial capital outlays. 
Table 1. Summary of descriptive features of all currently registered CDM projects in Small Island Developing States as at 1 March 2011

\begin{tabular}{|c|c|c|c|c|c|c|c|c|}
\hline Project features & $\begin{array}{c}\text { Vaturu and } \\
\text { Wainikasou } \\
\text { Hydro Projects }\end{array}$ & $\begin{array}{l}\text { Wigton Wind } \\
\text { Farm Project }\end{array}$ & $\begin{array}{c}\text { Lihir } \\
\text { Geothermal } \\
\text { Power Project }\end{array}$ & $\begin{array}{l}\text { El Guanillo Wind } \\
\text { Farm }\end{array}$ & $\begin{array}{c}\text { Energas } \\
\text { Varadero Project }\end{array}$ & $\begin{array}{l}\text { Bagasse } \\
\text { Cogeneration } \\
\text { Project }\end{array}$ & $\begin{array}{c}\text { Thermal Energy } \\
\text { Project }\end{array}$ & $\begin{array}{l}\text { Landfill Methane } \\
\text { Project }\end{array}$ \\
\hline Registration Date & October 2005 & March 2006 & May 2006 & October 2006 & June 2007 & May 2008 & November 2008 & February 2009 \\
\hline $\begin{array}{l}\text { Host } \\
\text { Country }\end{array}$ & Fiji & Jamaica & PNG & Dominican Republic & Cuba & Guyana & Singapore & Cuba \\
\hline $\begin{array}{l}\text { Scope } \\
\text { and Type }\end{array}$ & $\begin{array}{l}\text { Energy; hydro } \\
\text { power }\end{array}$ & $\begin{array}{l}\text { Energy; wind } \\
\quad \text { Power }\end{array}$ & $\begin{array}{l}\text { Energy; } \\
\text { geothermal }\end{array}$ & Energy; wind power & $\begin{array}{l}\text { Energy; energy } \\
\text { efficiency }\end{array}$ & Energy; biomass & Energy; biomass & $\begin{array}{l}\text { Energy and waste; methane } \\
\text { utilization }\end{array}$ \\
\hline Scale & Small & Large & Large & Large & Large & Large & Small & Large \\
\hline Developer & $\begin{array}{c}\text { Sustainable } \\
\text { Energy Limited }\end{array}$ & $\begin{array}{l}\text { Petroleum } \\
\text { Corporation of } \\
\text { Jamaica }\end{array}$ & $\begin{array}{l}\text { Lihir } \\
\text { Management } \\
\text { Company }\end{array}$ & $\begin{array}{l}\text { Parques Eólicos del } \\
\text { Caribe }\end{array}$ & Energas & $\begin{array}{l}\text { Guyana Sugar } \\
\text { Corporation }\end{array}$ & Bee Joo Industries & Biogases del Sur; Bionersis \\
\hline Other Participants & $\begin{array}{l}\text { ABN AMRO } \\
\text { Bank }\end{array}$ & $\begin{array}{l}\text { The Netherlands } \\
\text { Development } \\
\text { Finance Company }\end{array}$ & $\begin{array}{l}\text { Lihir Gold Ltd; } \\
\text { Barclays Bank }\end{array}$ & Gamesa Energia & $\begin{array}{l}\text { Sherritt } \\
\text { International } \\
\text { Corporation }\end{array}$ & $\begin{array}{l}\text { The aid agencies } \\
\text { of numerous } \\
\text { European } \\
\text { governments }\end{array}$ & $\begin{array}{l}\text { The Kansai Electric } \\
\text { Power Company }\end{array}$ & $\begin{array}{l}\text { Bionersis; } \\
\text { Sociedad Para El Desarrollo } \\
\text { Limpio En America Latina }\end{array}$ \\
\hline Project Lifespan & 50 years & 20 years & 30 years & 20 years & 25 years & 20 years & 21 years & 15 years \\
\hline $\begin{array}{l}\text { Projected Yield } \\
\text { (CERs/yr) }\end{array}$ & 24,928 & 52,540 & 278,904 & $123,916 \mathrm{tCO}_{2} \mathrm{e}$ & $342,235 \mathrm{tCO}_{2} \mathrm{e}$ & $44,733 \mathrm{tCO}_{2} \mathrm{e}$ & $15,205 \mathrm{tCO}_{2} \mathrm{e}$ & $123,162 \mathrm{tCO}_{2} \mathrm{e}$ \\
\hline
\end{tabular}


Table 2. Summary of sustainable development features and barriers to the development of all currently registered CDM projects in Small Island Developing States as at 1 July 2009

\begin{tabular}{|c|c|c|c|c|c|c|c|c|}
\hline & $\begin{array}{c}\text { Vaturu and } \\
\text { Wainikasou } \\
\text { Hydro } \\
\text { Projects } \\
\end{array}$ & $\begin{array}{l}\text { Wigton } \\
\text { Wind } \\
\text { Farm } \\
\text { Project } \\
\end{array}$ & $\begin{array}{c}\text { Lihir } \\
\text { Geothermal } \\
\text { Power } \\
\text { Project } \\
\end{array}$ & $\begin{array}{c}\text { El } \\
\text { Guanillo } \\
\text { Wind } \\
\text { Farm } \\
\end{array}$ & $\begin{array}{c}\text { Energas } \\
\text { Varadero } \\
\text { Project }\end{array}$ & $\begin{array}{c}\text { Bagasse } \\
\text { Cogeneration } \\
\text { Project }\end{array}$ & $\begin{array}{l}\text { Thermal } \\
\text { Energy } \\
\text { Project }\end{array}$ & $\begin{array}{c}\text { Landfill } \\
\text { Methane } \\
\text { Project }\end{array}$ \\
\hline \multicolumn{9}{|c|}{ Sustainable development and other benefits to the host country stated in the project design document } \\
\hline $\begin{array}{l}\text { Replaces the use of fossil } \\
\text { fuels }\end{array}$ & $\checkmark$ & $\checkmark$ & $\checkmark$ & $\checkmark$ & $\checkmark$ & $\checkmark$ & & $\checkmark$ \\
\hline $\begin{array}{l}\text { Reduces reliance on imported } \\
\text { fossil fuels }\end{array}$ & & $\checkmark$ & & & $\checkmark$ & & & \\
\hline $\begin{array}{l}\text { Diversifies sources of energy } \\
\text { generation }\end{array}$ & $\checkmark$ & $\checkmark$ & $\checkmark$ & $\checkmark$ & $\checkmark$ & $\checkmark$ & & $\checkmark$ \\
\hline Creates employment & $\checkmark$ & $\checkmark$ & $\checkmark$ & $\checkmark$ & $\checkmark$ & $\checkmark$ & $\checkmark$ & $\checkmark$ \\
\hline $\begin{array}{l}\text { Improvement in local air } \\
\text { quality }\end{array}$ & & & & & $\checkmark$ & & & \\
\hline Involves foreign investment & & & $\checkmark$ & & $\checkmark$ & $\checkmark$ & & $\checkmark$ \\
\hline $\begin{array}{l}\text { Supports community-based } \\
\text { projects }\end{array}$ & & & & & & & $\checkmark$ & \\
\hline $\begin{array}{l}\text { Improves waste management } \\
\text { practices }\end{array}$ & & & & & & $\checkmark$ & & $\checkmark$ \\
\hline
\end{tabular}


Table 2. (cont.)

\begin{tabular}{|c|c|c|c|c|c|c|c|c|}
\hline & $\begin{array}{c}\text { Vaturu and } \\
\text { Wainikasou } \\
\text { Hydro } \\
\text { Projects } \\
\end{array}$ & $\begin{array}{l}\text { Wigton } \\
\text { Wind } \\
\text { Farm } \\
\text { Project } \\
\end{array}$ & $\begin{array}{c}\text { Lihir } \\
\text { Geothermal } \\
\text { Power } \\
\text { Project } \\
\end{array}$ & $\begin{array}{c}\text { El } \\
\text { Guanillo } \\
\text { Wind } \\
\text { Farm } \\
\end{array}$ & $\begin{array}{c}\text { Energas } \\
\text { Varadero } \\
\text { Project }\end{array}$ & $\begin{array}{c}\text { Bagasse } \\
\text { Cogeneration } \\
\text { Project }\end{array}$ & $\begin{array}{l}\text { Thermal } \\
\text { Energy } \\
\text { Project }\end{array}$ & $\begin{array}{l}\text { Landfill } \\
\text { Methane } \\
\text { Project }\end{array}$ \\
\hline \multicolumn{9}{|c|}{ Barriers to project development as stated in the project design document } \\
\hline Sovereign risk of investment & $\checkmark$ & $\checkmark$ & $\checkmark$ & $\checkmark$ & $\checkmark$ & & $\checkmark$ & $\checkmark$ \\
\hline $\begin{array}{l}\text { Lack of skills in host country } \\
\text { workforce }\end{array}$ & $\checkmark$ & $\checkmark$ & & & & & & \\
\hline $\begin{array}{l}\text { Lack of government support } \\
\text { for renewable energy } \\
\text { development }\end{array}$ & & $\checkmark$ & $\checkmark$ & $\checkmark$ & $\checkmark$ & & $\checkmark$ & $\checkmark$ \\
\hline $\begin{array}{l}\text { Financial constraints - } \\
\text { including low electricity } \\
\text { prices and capital costs }\end{array}$ & $\checkmark$ & & & & $\checkmark$ & $\checkmark$ & $\checkmark$ & $\checkmark$ \\
\hline $\begin{array}{l}\text { Difficulties getting biomass } \\
\text { suppliers to change business } \\
\text { practices }\end{array}$ & & & & & & $\checkmark$ & & \\
\hline
\end{tabular}


There are a range of CDM project activities that have potential applicability in Pacific Island Countries (Pacific Consultants Ltd, 2002; Roper, 2005; McGregor, 2009) arising from PICs' reliance on diesel-based electricity generation, considerable renewable energy resources, and the importance of subsistence agriculture. McGregor (2009) identified renewable energy, waste management, energy efficiency and forestry as project activities with the greatest CDM potential. Most PICs have plentiful renewable energy sources, including solar, wind, hydro and geothermal resources (IGES, 2004; Roper, 2005). However, stand-alone renewable energy projects are likely to remain relatively unattractive to CDM developers in the Pacific for a number of reasons. As illustrated by Ellis and Kamel (2007), renewable energy projects including geothermal, wind and hydro have been shown to incur high investment costs relative to their CER returns. Additional studies have found that these project types yield low internal rates of return, being hampered by distortions in national energy markets (Austrade, 2008). Finally, renewable energy projects incur high investment costs. Thus, due to limited awareness, low technical and institutional capacity and financial constraints facing PICs, it is unlikely that these projects will be viable in the short term.

The potential for afforestation and reforestation (A/R) opportunities in the Pacific is contentious, with wide variability in the estimates of the possible scale of such activities (McGregor, 2009). Regardless of the availability of appropriate land, the constraints are prohibitive. Firstly, the process of developing methodologies for calculating, monitoring, and verifying emission reductions is particularly complex and difficult for A/R projects (McGregor, 2009; Thomas et al., 2010). Compared to direct fossil fuel emissions, the measurement of terrestrial carbon sequestration is difficult and imprecise (Thomas et al., 2010). Given the lack of access to CDM technical expertise in PICs, A/R projects are likely to be relatively less attractive than others. Also, the financial viability of $A / R$ projects is precarious. CERs generated from $A / R$ projects are currently excluded from the largest emission trading system, the EU ETS (McGregor, 2009). In addition, as noted by Thomas et al. (2010), a delay in the immediacy of financial returns, due to the years required to yield sequestration benefits from a newly planted forest, is a major disincentive for landholders.

Opportunities for energy efficiency projects in PICs are promising. Increasing the efficiency of fossil fuel plants and reducing power loss from electricity transmission and distribution have been identified as high priority projects (Pacific Consultants Ltd, 2002). McGregor (2009) reported that the Fiji Department of Energy in cooperation are currently engaged in demand-side energy efficiency projects. However, the absence of large-scale energy users and the high costs of maintaining the complicated technology impair the economic viability of these projects (Duic et al., 2003; McGregor, 2009).

Lower investment costs and the capacity to incorporate renewable energy generation make agricultural projects attractive CDM project propositions in PICs. The agricultural scope includes biogas from waste, biomass from agricultural residues, 
methane emissions avoidance, and methane recovery and utilization (UNFCCC, 2009b). A number of agricultural project opportunities have been identified in PICs, including effective utilization of biomass such as coconuts; methane fermentation and biogas utilization from livestock waste; and improving efficiency of biomass fuel utilization at a household level (Pacific Consultants Ltd, 2002). Roper (2005) highlighted the potential to produce biofuels from inexpensive and widespread sources including sugar cane and coconut oil, although Schlamadinger and Jürgens (2004) argued that a lack of investment in modern equipment means biofuels are often used in an unsustainable and inefficient manner. Waste management is another challenge for PICs, and available technologies that permit the generation of energy from waste could be readily applied (Roper, 2005; Raturi, 2008). Moreover, biogas projects that avoid methane emissions may have a comparative advantage over other project types, because they tend to yield high numbers of CERs but involve low investment costs (Ellis and Kamel, 2007; Austrade, 2008). CDM investment would not only achieve emissions reductions, but contribute to the sustainable development of rural areas by reducing the exploitation of natural resources.

\section{LESSONS FROM REGISTERED AGRICULTURAL CDM PROJECTS}

As at 1 July 2009, there were 1699 registered CDM projects, and 122 of these were listed under sectoral scope 15 (agriculture). Table 3 presents a comparison of descriptive statistics of the total project registry (i.e. all registered CDM projects) versus agricultural projects. The total number of expected CERs from agricultural projects is 8,241,170 $\mathrm{tCO}_{2} \mathrm{e}$ representing less than $3 \%$ of total volume of expected CERs from the CDM project registry as a whole. The mean number of CERs generated by all registered agricultural CDM projects $\left(67,575 \mathrm{tCO}_{2} \mathrm{e}\right)$ is considerably less than the mean number of CERs generated by the total registry of CDM projects $\left(180,990 \mathrm{tCO}_{2} \mathrm{e}\right)$. The median number of CERs generated by agricultural projects is also smaller $\left(45,943 \mathrm{tCO}_{2} \mathrm{e}\right.$ vs. $\left.47,823 \mathrm{tCO}_{2} \mathrm{e}\right)$ but the difference is less pronounced. However, the variance of expected CERs from agricultural projects (standard error $6,511 \mathrm{tCO}_{2} \mathrm{e}$ ) is far less than that of the total registry of projects (standard error $\left.16,853 \mathrm{tCO}_{2} \mathrm{e}\right)$. 
Table 3. Statistics of agricultural CDM projects compared to all CDM project

\begin{tabular}{lcc}
\hline $\begin{array}{l}\text { Annual expected CERs } \\
\text { (in tCO } \mathbf{2} \text { ) }\end{array}$ & $\begin{array}{c}\text { All registered CDM } \\
\text { projects (all types) }\end{array}$ & $\begin{array}{c}\text { All registered agricultural } \\
\text { projects }\end{array}$ \\
\hline Mean & $1,809,911$ & 67,575 \\
Standard Error & 16,853 & 6511 \\
Median & 47,823 & 45,942 \\
Range & $10,437,076$ & 379,519 \\
Minimum & 173 & 1415 \\
Maximum & $10,437,249$ & 380,934 \\
Sum & $307,503,165$ & $8,244,170$ \\
Count & 1699 & 122 \\
\hline
\end{tabular}

Agricultural CDM projects may be of four types: biogas, biomass, methane avoidance, and methane recovery and utilization. Table 4 provides a summary of the expected number of CERs produced by each type of registered agricultural CDM project. Biogas projects are the most common form of registered agricultural CDM projects ( $80 \%$ by number and $60 \%$ by volume). Methodologies based on animal waste (AM0016, AM0006 and ACM0010) were typically large projects, with expected average annual CERs of over $75,000 \mathrm{tCO}_{2} \mathrm{e}$ per project. Small-scale projects comprised over a third of all registered agricultural CDM projects but generated only $11 \%$ of expected CERs. Thirty-two of the 122 registered agricultural CDM projects were biogas projects that involved methane recovery from animal manure management systems. These biogas projects had an average expect annual yield of $17,250 \mathrm{tCO}_{2} \mathrm{e}$ CERs per project, representing about $25 \%$ of the expected CERs generated by all registered agricultural projects.

Biomass projects account for around 15\% of all registered agricultural CDM projects but are expected to generate about $35 \%$ of all CERs. Biomass project are expected to produce on average over 155,000 CERs annually, which is more than twice the average CERs generated by all agricultural projects. All of the biomass projects are based on the AMS-IIIE methodology, which entails the avoidance of methane production from decay of biomass through controlled combustion, gasification or mechanical or thermal treatment. All but one of the biomass projects were devised in combination with an energy-generating methodology. In total, 13 distinct combinations of combined methodologies have been applied to agricultural projects, all of which involve energy generation. It is evident that projects employing combined methodologies produce more CERs than projects that use a single methodology. The mean number of annual CERs generated by projects registered 
using a single methodology is 62,973, which is less than the mean number generated by projects using combined methodologies $(74,919)$.

Table 4. Expected CERs produced by different types of registered agricultural CDM projects

\begin{tabular}{|c|c|c|c|c|}
\hline Type of project & $\begin{array}{l}\text { Additional } \\
\text { information }\end{array}$ & $\begin{array}{c}\begin{array}{c}\text { Large- } \\
\text { scale } \\
\text { (tCO }\end{array} \text { e } \\
\text { CERs) }\end{array}$ & 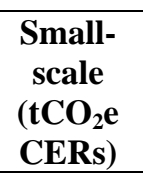 & $\begin{array}{c}\text { Total } \\
\left(\text { tCO }_{2} \mathrm{e}\right. \\
\mathrm{CERs})\end{array}$ \\
\hline \multirow[t]{2}{*}{ Biogas } & Animal waste & 74,982 & 16,860 & 53,101 \\
\hline & $\begin{array}{l}\text { Wastewater } \\
\text { treatment }\end{array}$ & - & 28,442 & 28,442 \\
\hline Biogas Total & & 74,982 & 20,206 & 49,830 \\
\hline \multirow[t]{3}{*}{ Biomass } & $\begin{array}{l}\text { Empty fruit bunch } \\
\text { oil palm }\end{array}$ & - & 192,663 & 192,663 \\
\hline & Others & - & 160,091 & 160,091 \\
\hline & Rice husk & - & 42,816 & 42,816 \\
\hline Biomass Total & & - & 155,288 & 155,288 \\
\hline Methane avoidance & & - & 108,847 & 108,847 \\
\hline $\begin{array}{l}\text { Methane recovery and } \\
\text { utilization }\end{array}$ & & - & 41,911 & 41,911 \\
\hline Total & & 74,982 & 61,885 & 67,575 \\
\hline
\end{tabular}

The disparity in the mean number of expected CERs from agricultural projects compared to the population of projects can be partially attributed to scale. Large-scale projects are less prevalent in agriculture. Large-scale projects account for $56 \%$ of projects and generate $93 \%$ of all CERs. In comparison, only $43 \%$ of agricultural projects are large-scale, and generate $48 \%$ of agricultural CERs. Large-scale agricultural projects, which are solely animal waste biogas projects, generate an average of about 75,000 CERs, far below the average of all large-scale projects. In contrast, small-scale agricultural projects are typically high yielding, generating an average of almost 62,000 CERs per project, which is $226 \%$ higher than the mean number of CERs generated by registered small-scale projects of all types.

Agricultural projects have been established in 17 countries but have been concentrated in Asia and Latin America. The top three countries by number of registered projects are Brazil (29\%), Mexico (20\%) and the Philippines (15\%). By 
comparison, the top three countries by annual CERs expected from agricultural projects are Brazil (38\%), Mexico (19\%) and Malaysia (19\%). Expected annual CERs from CDM projects in the Philippines, which are all biogas projects, account for only $1.45 \%$ of the total. Most of agricultural projects have involved a project participant from at least one Annex 1 country, and $40 \%$ of all projects have involved two or more participants. Of the Annex 1 countries involved in agricultural projects, the UK and Switzerland have been engaged most frequently, participating in $62 \%$ and $38 \%$ of the projects respectively. Notably, $13 \%$ of all registered agricultural projects were unilateral CDMs (projects registered without an Annex 1 party letter of approval). The mean number of CERs generated by these projects $(29,187)$ was appreciably less than the mean CERs generated by all agricultural projects $(67,575)$.

\section{DISCUSSION}

The data analysis presented in this paper supports the proposition that agricultural CDM projects are an attractive prospect for PICs. The high yields of combined biomass and energy production projects support the potential for coconut-based biomass identified by existing studies (Pacific Consultants, 2002; Leplus, 2003; SOPAC, 2007). A CDM project involving the harvesting and processing of coconut biomass would generate CERs by avoiding methane emissions from the decay of coconuts and replacing diesel-based electricity. In addition, it would create development benefits by stabilizing the market for coconut products, thus spurring new income-generating opportunities, reducing land degradation and improving village energy autonomy (Leplus, 2003; Boyd et al., 2009; SOPAC, 2007).

There are various barriers that could prevent PICs from developing these sorts of CDM projects. The fact that there are so few agricultural projects, particularly ones that involve methane avoidance, indicates that the level of risk perceived by developers and investors is high. PICs may encounter considerable difficulty in attempting to attract foreign investors before CERs have been generated. Another barrier is the absence of specific agricultural methodologies, particularly ones that consolidate agricultural activities with energy generation. Having to apply multiple methodologies to a project will increase the complexity and costs of developing the PDD and monitoring emission reductions. This will in turn further constrain the ability of PICs to obtain project financing.

Considering the opportunities and challenges facing PICs, the pertinent question is how they can best engage with the CDM. Principally, PICs need to undertake institutional and regulatory reforms that will encourage investment. Reforms need to focus on strengthening property rights and financial systems, reducing enterprise costs and providing appropriate incentives (Holden et al., 2004). Dismantling state monopolies in electricity generation and distribution should promote competition favouring renewable energy technologies (Holden et al., 2004; McGregor, 2009). In addition, there is a need for PICs to ensure that their trade and fiscal policies favour 
investment by removing tariffs and providing tax incentives for businesses (Ellis and Kamel, 2007, McGregor, 2009). The financial sector should be engaged to improve credit availability to entrepreneurs and increase the diffusion of CDM-related knowledge. One suggestion to address this issue is to adopt a regional approach to CDM investment (Byrne et al., 2005; Van den Berg and Langenberg, 2006). Van den Berg and Langenberg (2006) suggested building regional institutions that would assemble national resources and knowledge into a central hub for project developers, technical practitioners and governments. A central hub of information would encourage the propagation of CDM knowledge and reduce perceived investment risk. Van den Berg and Langenberg (2006) also favoured the implementation of a regional financing mechanism that would facilitate project development. Byrne et al. (2005) argued that a regional system should streamline contract conditions and set criteria for assessing preferred project types. This would promote investment from developed countries by reducing transaction costs.

Another potential approach is for PICs to pursue unilateral projects where equity is sourced domestically, with Annex I credit buyers involved only after certification (Laseur, 2005). Unilateral CDMs may induce positive changes in risk perceptions and cost patterns. Furthermore, host country investors are likely to place greater value on the non-market sustainable development benefits from local projects, further improving the benefit/cost ratios (Laseur, 2005). Unilateral projects have lower transaction costs because transactional expenses and bureaucratic hurdles are avoided. In PICs, unilateral projects could encourage small village-based projects which generate relatively few CERs but have considerable development benefits and are generally neglected by foreign investors. Unilateral projects also ensure that all financial returns from the project remain in the host country, because there is no transfer to a foreign partner.

There are two obvious and significant constraints limiting the ability of PICs to pursue unilateral activities. Unilateral projects must rely solely on domestic capital markets for financing, which in PICs are limited. Also, the host countries must possess the necessary expertise and institutional capacity to implement projects, both of which have already been identified as major constraints to CDM project development (Sieghart, 2009). A further constraint is that there is no potential to realize benefits from technology transfer. Individually PICs are unlikely to possess the necessary resources and capacity to engage in unilateral CDMs yet a regional system capable of pooling resources to overcome these constraints could potentially support technology transfer.

In order to encourage CDM activities, Pacific Island Countries will have to engage in targeted technical and institutional capacity building, for which they will require the assistance of their developed neighbours, including Australia and New Zealand. Aid efforts hitherto have concentrated on adaptation measures aimed at improving resilience and increasing awareness of climate change impacts, as opposed to mitigation-related activities (AusAid, 2009; McGregor, 2009). Although the 
Australian Government's published policy on Pacific climate change engagement does not mention the CDM (Department of Climate Change, 2009), it is logical that Australia should assist PICs in building the capacity necessary to participate, because projects that improve energy stability will serve to strengthen adaptation measures and improve development sustainability. Such engagement will also boost Australia's renewable energy industry, creating new investment opportunities for Australian companies offering renewable energy systems, finance and consultancy. To assist in building capacity in PICs, the governments of regional economic leaders including Australia and New Zealand need to explore the potential for a regional CDM body or investment fund and assist in initiating and improving the functioning of DNAs in the Asia-Pacific region. In relation to agricultural projects, initial development costs and administrative constraints could be reduced by sponsoring the development of new agriculture-based methodologies that are tailored to the unique characteristics of PICs.

PICs will be among those most adversely affected by climate change; they are simultaneously highly vulnerable and poorly equipped to respond. The CDM offers a means through which PICs can contribute to mitigation while improving their adaptive capacity and encouraging sustainable development. Despite the region's minimal contribution to emissions, PICs have considerable potential to engage in CDM projects. However, in the presence of inhibitive institutional, informational, financial and geographic and demographic barriers, more CDM projects have failed to materialize. This paper has identified agricultural projects as having substantial potential for development in PICs. In particular, small-scale biomass projects that incorporate energy generation present a feasible opportunity. In order to realize this potential, PICs will need to improve their approach to facilitating CDM investment. This must encompass reforms to improve institutional and regulatory efficiency, which will in turn instil the confidence and incentives required to attract investors. In addition, proposals to establish a regional Pacific CDM body capable of pooling scarce resources, or the promotion of unilateral projects, warrant further investigation. Finally, PICs should seek assistance from their developed neighbours, notably Australia and New Zealand, in developing specific capacities. By supporting CDM initiatives, Australia and New Zealand will contribute to improving the standard of living of its Pacific neighbours, while fostering comparative advantages in its renewable energy industries.

\section{REFERENCES}

AUSAID (AUSTRALIAN AGENCY FOR INTERNATIONAL DEVELOPMENT). 2009. Aid Activities: Climate Change and Environment in the Pacific. Canberra. http://www.ausaid.gov.au/country/pacific/climate_change.cfm. Accessed 11 October 2009. 
AUSTRADE (Australian Trade Commission). 2008. Regional Export Opportunities for Australia's Clean Energy Industry. Renewable Energy and Energy Efficiency Partnership and Clean Energy Council, Australia.

BOYD, E., HULTMAN, N., TIMMONS ROBERTS, J., CORBERA, E., COLE, J., BOZMOSKI, A., EBELING, J., TIPPMAN, R., MANN, P., BROWN, K. and D. LIVEMAN. 2009. Reforming the CDM for sustainable development: lessons learned and policy futures. Environmental Science and Policy. 12(7): 820-831.

BURNS, W. 2000. The impact of climate change on Pacific Island developing countries in the 21st Century. In: A. Gillespie, W. Burns (eds), Climate Change in the South Pacific: Impacts and Responses in Australia, New Zealand, and Small Island States. Kluwer Academic Publishers, the Netherlands.

BYRNE, J., GLOVER, L., INNISS, V. and G. ALLENG. 2005. Island Bellwether: Climate Change and Energy Policy Strategy for Small Island Developing States. Toward Mauritius 2005. Paper Series No. 2005-2, Centre for Energy and Environmental Policy, University of Delaware, USA.

CAPOOR, K. and P. AMBROSI. 2009. State and Trends of the Carbon Market 2009. The World Bank, Washington DC.

DEPARTMENT OF CLIMATE CHANGE. 2009. Engaging our Pacific Neighbours on Climate Change: Australia's Approach. Commonwealth of Australia. http://www.climatechange.gov.au/en/publications/international/engaging-pacificneighbours.aspx. Accessed 1 March 2010.

DUIC, N., ALVES, L.M., CHEN, F. and M. DA GRACA CARVALHO. 2003. Potential of Kyoto Protocol Clean Development Mechanism in transfer of clean energy technologies to Small Island Developing States: case study of Cape Verde. Renewable and Sustainable Energy Reviews. 7(1): 83-98.

ELLIS, J. and S. KAMEL. 2007. Overcoming Barriers to Clean Development Mechanism. Organization for Economic Cooperation and Development and International Energy Agency. Washington, DC.

ENERGAS. 2006. Energas Varadero Conversion from Open Cycle to Combined Cycle Project. CDM-Project Design Document, v 3.1. Report prepared for CDM Executive Board, Bonn, Germany.

ETUATI, K. 2008. Gender and Climate Change: Women for Climate Change, 'Challenges and Recommendations for Clean Development Mechanism Aiming to Improve Women's Livelihoods in the Pacific Region', report prepared by Pacific Islands Applied Geoscience Commission (SOPAC).

FAO (FOOD AND AGRICULTURE ORGANIZATION OF THE UNITED NATIONS). 2008. Climate Change and Food Security in Pacific Island Countries, Rome, http://www.fao.org/docrep/011/i0530e/i0530e00.HTM. Accessed 1 March 2010.

GRASSO, M. 2006. An ethics-based climate agreement for the South Pacific Region. International Environmental Agreements: Politics, Law and Economics. 6(3): 249270.

HABERKORN, G. 2004. Current Pacific population dynamics and resent trends. SPC Demography/Population programme. http://www.spc.int/demog/en/index.html. Accessed 1 March 2010. 
HOLDEN, P., BALE, M., and S. HOLDEN. 2004. Swimming against the Tide? An Assessment of the Private Sector in the Pacific. Asian Development Bank.

IGES (INSTITUTE FOR GLOBAL ENVIRONMENTAL STRATEGIES) 2009. IGES CDM Project Database, K. Iyadome (Editor). http://www.iges.or.jp/ en/cdm/report.html. Accessed 1 March 2010.

IGES. 2004. Clean Development Mechanism in the Pacific island countries - issues and challenges. In: Proceedings from international workshop, Facilitating Adaptation to Climate Change in the South Pacific Region - Bridging Research, Policy, and Implementation, 12-14 October 2004, SPREP Training and Education Centre, Apia, Samoa. http://enviroscope.iges.or.jp/modules/envirolib/view.php?docid=147. Accessed 1 March 2010.

IROI, C., YEE, D. and M. LAM (n.d.), The Capacity of Solomon Islands to Meet its Obligation Under the United Nations Framework Convention on Climate Change A National Capacity Self-Assessment. Solomon Islands Meteorological Service.

JAHN, M., MICHAELOWA, A., RAUBENHEIMER, S. and H. LIPTOW. 2004. Measuring the Potential of Unilateral CDM - A Pilot Study. Discussion Paper 263, Hamburg Institute of International Economics (HWWA), Hamburg, Germany.

KWA, E.K. 2008. Climate change and indigenous people in the South Pacific. Paper presented to the IUCN Academy of Environmental Law Conference on Climate Law in Developing Countries post-2012: North and South Perspectives. Ottawa, Canada, 26-28 September.

LASEUR, J. 2005. Unilateral CDM - Addressing the participation of developing countries in CDM project development. International Economics and Business Masters Thesis, University of Groningen, the Netherlands.

LEPLUS, A. 2003. Bioenergy from Coconut: the Lory Cooperative Pilot Project. Unpublished PhD Thesis, Secretariat of the Pacific Community, Wageningen University, The Netherlands

MCGREGOR, K. 2009. Barriers to CDM projects in Pacific Island countries: a focus on Fiji. Pacific Economic Bulletin. 24(1):161-173.

OLSEN, K.H. 2007. The Clean Development Mechanism's contribution to sustainable development: a review of the literature. Climatic Change. 84(1): 59-73

PACIFIC CONSULTANTS LIMITED. 2002. Identification of Opportunities for Pacific Island Countries and Japan to Collaborate through the Clean Development Mechanism (CDM) of the Kyoto Protocol. http://gec.jp/gec/en/Activities/ cdm/FS200107SE.pdf. Accessed 12 October 2011.

PACIFIC ISLANDS APPLIED GEOSCIENCE COMMISSION (SOPAC). 2007. Liquid Biofuels in Pacific Island Countries, SOPAC Miscellaneous Report 628, prepared by J. Cloin, A. Woodruff and D. Fürstenwerth.

PACIFIC REGIONAL ENVIRONMENT PROGRAMME (SREP). 2005. Pacific Islands Framework for Action on Climate Change 2006-2015. http://www.sprep.org/publication/pub_detail.asp?id=438. Accessed 12 October 2011.

RATURI, A. 2008. CDM and the Pacific Island Countries - Opportunities and challenges. Presented at JICA-CDM TV seminar, Suva. 
ROPER, T. 2005. Small island states - setting an example on green energy use. Review of European Community and International Environmental Law. 14(2):108-116

SCHLAMADINGER, B. and I. JÜRGENS. 2004. Bioenergy and the Clean Development Mechanism. Presented at the 2nd World Conference on Biomass for Energy, Industry and Climate Protection, 10-14 May 2004, Rome.

SIEGHART, L. 2009. Unilateral Clean Development Mechanism - an approach for a least developed country? The case of Yemen. Environmental Science and Policy. 12(2): 198-203.

THE WORLD BANK. 2007. Cheap, Reliable and Renewable Electricity a Step Closer for Pacific Islanders, Press Release No 2007/440/EAP, June 122007. http://web.worldbank.org/WBSITE/EXTERNAL/COUNTRIES/EASTASIAPACIF ICEXT/PACIFICISLANDSEXTN/0,,contentMDK:21369612 menuPK:441893 pa gePK:2865066 piPK:2865079 theSitePK:441883,00.html. Accessed 10 May 2009.

THOMAS, S., DARGUSCH, P., HARRISON, S. and J. HERBOHN. 2010. Why are there so few afforestation-based CDM projects? Land Use Policy. 27(3); 880-887.

UNDP (UNITED NATIONS DEVELOPMENT PROGRAM). 2003. The Clean Development Mechanism: a User's Guide, Energy and Environment Group/Bureau for Development Policy, New York.

UNDESA (UN DEPARTMENT OF ECONOMIC AND SOCIAL AFFAIRS) 2009. Small Island Developing States, Division of Sustainable Development. http://www.un.org/esa/sustdev/sids/sidslist.htm. Accessed 12 October 2011.

UNFCCC (UNITED NATIONS FRAMEWORK CONVENTION ON CLIMATE CHANGE). 2009a. Clean Development Mechanism: 2008 in Brief.

UNFCCC (United Nations Framework Convention on Climate Change). 2009b. CDM Statistics. http://cdm.unfccc.int/Statistics/index.html, Accessed 7 September 2009.

VAN DEN BERG, J.B. and J.W. LANGENBERG. 2006. Barriers and Chances Facing Caribbean Clean Development Mechanism Projects. Report prepared for BSC Systems Engineering, Policy Analysis and Management, Delft University of Technology, The Netherlands.

VAN DER VELDE, M., GREEN, S.R., VANCLOOSTER, M. and B.E. CLOTHIER. 2007. Sustainable development in small island developing states: agricultural intensification, economic development, and freshwater resources management on the coral atoll of Tongatapu. Ecological Economics. 61(2-3): 456-468. 